\title{
Implementation of Character Education through Learning Pancasila and Citizenship Education in Sungguminasa 1 State Junior High School, Gowa Regency
}

\author{
Andi Sugiati ${ }^{1)}$, Jumiati Nur ${ }^{2)}$, Nurannisah Anwar ${ }^{3)}$ \\ Pancasila and Citizenship Education Study Program, Teacher Training and Education Faculty, \\ Muhammadiyah University of Makassar, Jl. Sultan Alauddin No.259, Makassar, Indonesia 90221 1,2,3) \\ andisugiati@unismuh.ac.id, jumiatinur@unismuh.ac.id, nurannisahanwar@unismuh.ac.id
}

\begin{abstract}
The main problem in this study aims to describe the implementation of character education through learning Pancasila and Citizenship Education at Sungguminasa State Junior High School 1, Gowa Regency. This type of research is a qualitative descriptive study. The data collection techniques used were interviews, observation, and documentation. Data analysis techniques using data reduction steps, data presentation, and drawing conclusions. The results showed that the implementation of character education through learning Pancasila and Citizenship Education in the learning process of Pancasila and Citizenship Education in class VIII.B of the State Junior High School 1 Sungguminasa, Gowa Regency has been implemented by teachers through planning. In learning planning, there is a character value contained in self-development activities including routine, spontaneous and exemplary activities, while learning activities in the Learning Implementation Plan are in Core competencies and Basic Competencies (KD). There are several supporting factors experienced by teachers in learning Pancasila and Citizenship Education, namely, students create comfortable and conducive classes, teachers provide motivation and understanding of the importance of character values, provide role models, advice, rewards and punishments, and teachers create interesting learning and fun through the learning methods Student Active Learning and Collaborative Learning, while the inhibiting factors experienced by teachers in learning Pancasila and Citizenship Education, namely, Not conducive to learning Pancasila and Citizenship Education with student rest periods that make learning Pancasila and Citizenship education hampered and student learning enthusiasm decreases., and the inadequacy of printed books for students which triggers a lack of interest in reading in students is due to the lack of printed books and this also has an impact on students when they test.
\end{abstract}

Keywords: Character Education, Learning, Pancasila and Citizenship Education

\begin{abstract}
Abstrak. Masalah utama dalam penelitian ini bertujuan mendeskripsikan implementasi pendidikan karakter melalui pembelajaran Pendidikan Pancasila dan Kewarganegaraan di Sekolah Menengah Pertama Negeri 1 Sungguminasa Kabupaten Gowa. Jenis penelitian ini merupakan penelitian deskriptif kualitatif. Teknik pengumpulan data yang digunakan adalah wawancara, observasi, dan dokumentasi. Teknik analisis data dengan menggunakan langkah-langkah reduksi data, penyajian data, dan penarikan kesimpulan. Hasil penelitian diperoleh bahwa implementasi pendidikan karakter melalui pembelajaran Pendidikan Pancasila dan Kewarganegaraan dalam proses pembelajaran Pendidikan Pancasila dan Kewarganegaraan kelas VIII.B Sekolah Menengah Pertama Negeri 1 Sungguminasa Kabupaten Gowa telah dilaksanakan oleh guru melalui perencanaan. Dalam perencanaan pembelajaran adalah adanya nilai karakter yang termuat kegiatan pengembangan diri meliputi kegiatan rutin, spontan dan keteladanan sedangkan kegiatan belajar dalam Rencana Pelaksanaan Pembelajaran yaitu pada kompetensi Inti dan Kompetensi Dasar (KD). Terdapat beberapa faktor pendukung yang dialami guru dalam pembelajaran Pendidikan Pancasila dan Kewarganegaraan yaitu, siswa menciptakan kelas yang nyaman dan kondusif, guru memberikan motivasi dan pemahaman tentang pentingnya nilai-nilai karakter, memberikan teladan, nasihat, penghargaan dan hukuman, dan Guru menciptakan pembelajaran yang menarik dan menyenangkan melalui metode pembelajaran Student Active Learning dan Collaborative Learning, sedangkan faktor penghambat yang dialami guru dalam pembelajaran Pendidikan Pancasila dan Kewarganegaraan yaitu, Tidak kondusifnya pembelajaran Pendidikan Pancasila dan Kewarganegaraan dengan waktu istirahat siswa yang membuat pembelajaran Pendidikan Pancasila dan Kewarganegaraan terhambat dan semangat belajar siswa menurun, dan tidak memadainya buku cetak pada siswa yang memicu kurangnya minat baca pada siswa diakibatkan kurangnya buku cetak dan ini juga berdampak pada siswa ketika ulangan.
\end{abstract}

Kata Kunci: Pendidikan Karakter, Pembelajaran, Pendidikan Pancasila dan Kewarganegaraan . 


\section{INTRODUCTION}

Indonesia is currently experiencing a multidimensional crisis. The practice of KKN, murder, violence, rape, drug abuse, robbery, and plagiarism often occurs in Indonesia, both within the community and among state officials. This is due to a decline in the morale of the Indonesian people. the moral decline faced by the Indonesian nation is the main factor inhibiting the progress of the State. Overcoming the moral decline of the Indonesian nation is the obligation of all Indonesian citizens.

Recently, the term character education has emerged. Character education gets a lot of attention from the people of Indonesia. This is because people feel social inequality from the results of education. This imbalance can be seen from the behavior of formal education graduates at this time, for example, such as corruption, free sex, drugs, and brawls between students. One of the current problems is the low quality of education. This has an effect on student development. This phenomenon is caused by a lack of strong character education in students. Character education is a tool that plays an important role in creating quality and potential human beings. Therefore, it is necessary to have character education from the beginning, namely since childhood.

Article 1 of the 2003 National Education System Law states that among the goals of national education is to develop the potential of students to have intelligence, personality and noble character. Whereas in article 3 of the National Education System Law, it is stated that "National education has the function of developing and shaping the character and civilization of a nation with dignity in educating the nation's life, aiming to develop the potential of students to become human beings who believe and fear one God, noble, healthy, knowledgeable. , competent, creative, independent and become citizens of a democratic and responsible system. The aim of national education is a formulation of human quality that must be developed by each educational unit. Therefore, the formulation of the goals of national education becomes the basis for the development of education and national character.

According to John Dewey in Masnur Muslish, education is a process of building fundamental skills intellectually and emotionally towards nature and fellow humans. The purpose of education in this case is that the younger generation as the successor to the older generation can live, understand, practice these values and norms by inheriting all experiences of knowledge, abilities and skills that underlie the values and norms of life and life.

According to Ilahi, evidence of the failure of character education that can be seen in plain sight is the increasing number of brawls between students and between students. Like some big cities, student brawls have 
become a tradition and form a fixed pattern so that between them form sworn enemies. Brawls are also often carried out by students as is done by certain groups of university students in Makassar and in other areas. In the implementation of character education in Indonesia, the phenomenon of brawl between students and students is getting out of control, even spreading to various sides of life so that this situation creates unrest for public order and security at large.

Pancasila and citizenship education is basically one of the suggestions for shaping student academic behavior in learning. Pancasila and Citizenship Education has a close relationship in shaping behavior in everyday life in learning Pancasila and Citizenship Education. Students learn the application of the attitude of being good citizens. Therefore, the Pancasila and citizenship education process is manifested in the 2013 curriculum and learning at all paths and levels of national education, Pancasila and Citizenship Education should be designed, developed, implemented, and evaluated in the context of embodying the goals of national education.

As happened at the Junior High School, 2 students who were arrested by the police in 2018, were involved in a brawl between schools, two students of the State Junior High School 1 Sungguminasa were secured by police personnel, they were chasing each other and throwing stones at each other, causing traffic jams (tribuntimur. com)

He admitted, the issue of character or morals was not completely ignored by educational institutions. However, the facts surrounding the deterioration of character around us show that there is a failure in our educational institutions in terms of cultivating Indonesian people with noble character or morals. This is because what is taught in schools about religious knowledge and moral education has not succeeded in shaping human character. Yet if we look at the content of religious and moral lessons, everything is good, and we can even understand and memorize what it means. For this reason, the conditions and facts of character and moral decline that occur emphasize that teachers who teach any eyes must pay attention and emphasize the importance of character education in students.

After knowing how important character education is, what needs to be done is how we implement it in learning. Often when talking about character education, the first subjects that come to our minds are religious education and civic education. It is not wrong if we think like that, considering that in these subjects there is a lot of material that teaches behavior and attitudes. However, subjects that contain a lot of material on character education will also not function optimally in instilling character values if the 
education system or the process of planting also does not take place in the right ways.

\section{RESEARCH METHODS}

The type of research used in this research is descriptive research with a qualitative research method approach that produces descriptive data in the form of written or spoken words from people and observed behavior. Qualitative research method is a research method based on the philosophy of postpositivism used for research on natural object conditions, the researcher is the key instrument, data analysis is inductive / qualitative and the results of qualitative research emphasize the meaning rather than generalization.

The location that the research uses with regard to the title of this research is the implementation of character education through learning Pancasila and Citizenship Education at Sungguminasa State Junior High School 1, Gowa Regency, namely Sungguminasa State Junior High School 1, Gowa Regency, located in Somba Opu District, Gowa Regency. Meanwhile, the time of research on the implementation of character education was carried out on 19 August 2019 - 17 September 2019. The data sources in this study were primary and secondary data sources.

The object of research is the implementation of character education through the subjects of Pancasila and Citizenship Education. The subjects in this study were teachers of Pancasila and Citizenship Education at Sungguminasa 1 State Junior High School, Gowa Regency. There is one Pancasila and Citizenship Education teacher at Sungguminasa State Junior High School 1, Gowa Regency who teaches class VIII.B. Qualitative research suggests that the data collection techniques used for qualitative research can be done by means of interviews, observation and documentation.

\section{DISCUSSION}

Implementation of Character Education through Learning Pancasila and Citizenship Education in Sungguminasa 1 State Junior High School, Gowa Regency. School is a very strategic place for character building because most children, from all walks of life, are educated in school. In addition, children / students spend most of their active time in the school environment, so what they get at school will greatly affect their character building.

This is in accordance with the theory put forward by Daniel Goleman in Megawangi (2004: 77) that many parents fail to educate their children, children's social emotional maturity can be corrected by providing character education training to children at school, especially from an early age. .

This is reinforced by the function of national education as stated in Article 3 of the National Education System Law, that 
education is based on human beings who believe and fear God, have noble character.

From the description above, the researchers conclude that character education functions to develop and shape a dignified character and civilization of the nation in order to educate the nation's life, aims to develop the potential of students to become human beings who believe and fear God Almighty, have noble character, are healthy, knowledgeable, competent, creative, independent, and become democratic and responsible citizens.

The results of the research obtained through the analysis of observations, interviews, and documentation show that Pancasila and Citizenship Education teachers have implemented character education in the learning process of Pancasila and Citizenship Education in class VIII.B Sungguminasa State Junior High School 1, Gowa Regency through self-development activities including routine activities. , spontaneous, exemplary and learning activities through planning and the learning process. At the planning stage of the implementation of character education in learning through the Learning Implementation Plan. The Learning Implementation Plan analyzed was as much as one 2013 Curriculum Learning Implementation Plan, in which the Learning Implementation Plan contained several character values in the Core competencies.

The values listed in the core competencies in the teacher's lesson plan are religious, honesty, caring, discipline, responsibility, critical, polite, curiosity, independent, communicative, and confident. Some of these values have been developed by the teacher in their learning according to the results of the analysis of observations and interviews. This is based on the results of the teacher's Learning Implementation Plan documentation in the teacher learning process implementing several character values in Pancasila and Citizenship Education learning, such as implementing polite values through the opening and closing greetings that the teacher always does. Religious values are always implemented through prayer activities before and after learning. Teachers often present students to instill the value of discipline. Cultivating curiosity can be through the perception and use of materials, media, and methods. The teacher said that it always fosters students' curiosity through this.

This is based on the results of observations made on teachers where Pancasila and Citizenship Education learning activities carry out group discussion activities to instill the value of cooperation. Giving individual assignments is also often done by teachers to implement independent values, hard work, and responsibility. The final activity of learning is to conclude the results of the discussion to instill self-confidence. According to the results of the teacher's interview, it shows that the teacher's way of inviting students to dare to express opinions is 
by motivating students to believe that what is on their minds must be removed to get students used to speaking in front of other students.

According to Mulyasa, (2011) argues that the Characterized Learning Implementation Plan serves to streamline the learning process and build the character of students according to what is planned. This is in accordance with the opinion of Oemar Hamalik (2002) that teaching materials are an important part of the teaching and learning process related to the achievement of learning objectives, and determining teaching and learning activities. From the theoretical description, the researcher concludes that the Learning Implementation Plan serves to encourage each teacher to be ready to carry out learning activities, forming the competence and character of students. The character in Sungguminasa State Junior High School 1, Gowa Regency needs to be developed both in self-development and learning activities.

In learning Pancasila and Citizenship Education also uses positive and negative approaches. Positive reinforcement given by Pancasila and Citizenship Education teachers in the form of praise, applause, and encouragement to motivate students. Negative reinforcement has a deterrent effect on students who break the rules, behave and behave without character. When the attitudes and actions of students have no character, the first thing that the Pancasila and Citizenship Education teacher does is to give a warning, then give a warning, and finally give points that are enforced in Sungguminasa 1 State Junior High School, Gowa Regency.

This is in accordance with Sjarkawi's (2008) theory which states that the value planting approach seeks to make students recognize and accept values as their own and to be responsible for the decisions they make through stages, recognize choices, determine their stance to apply values according to selfbelief. The methods used in this approach include exemplary. This is in accordance with the opinion of Kohlberg (2004: 28) that a person's moral development also occurs automatically, but requires education and assistance so that this development can be true.

From the description of the opinion above, the researcher concludes that education must be able to develop student intelligence in accordance with the demands of the curriculum and challenges in the current global era, teachers develop student intelligence by using methods of showing or exemplifying both in learning and outside learning this is an effort to mature students. in making decisions.

Supporting in the Development of Character Education through Learning of Holistic-Based Pancasila and Citizenship Education in Sungguminasa 1 State Junior High School, Gowa Regency.

1. The teacher creates a comfortable and conducive classroom so that the development of character education 
through Pancasila and Citizenship Education can run well. Pancasila and Citizenship Education Learning is placed at the second hour, based on observations there is one class VIII in which Pancasila and Citizenship Education learning is carried out during the day. Where a comfortable class, good air cycle and good lighting. In addition, the teacher's ability to manage the classroom also has an influence on conducive learning so that students are not noisy and can concentrate on Pancasila and Citizenship Education subjects. According to the opinion of Rianto (2007: 1) that class management is an effort of educators to create and control learning conditions and improve in case of disturbances and deviations, so that the learning process can take place optimally. Organizing the learning environment is basically managing the learning environment, learning activities in managing the learning environment are more concentrated on managing the learning environment in the teacher's classroom, in arranging the learning environment in the classroom, doing nothing but doing classroom management activities.

2. The teacher provides motivation and understanding of the importance of character values and that the Pancasila and Citizenship Education subjects teach morals and character to equip students to behave and behave in society. According to the theory of Hellriegel and Slocum (1979) that motivation is a force that encourages someone to do something to achieve goals, this power is stimulated by various kinds of needs such as: wants to be fulfilled, behavior, goals, feedback. Based on research conducted by Elly Manizar (2017), it explains the role of teachers as motivators in learning, which is motivation to be very important for teachers to master as motivators in school, because teachers are the closest people and understand the situation of their students. Researchers agree that with the existence of student learning motivation has a driving force arising from the mental strength of students and from the creation of learning conditions in such a way as to achieve learning goals itself.

3. The teacher provides role models, advice, rewards and punishments, and accustoms students to behave and behave with character. By balancing this approach students become more aware of character values, appeal to provide knowledge of character values, then see the attitudes and behavior of the teacher according to words or appeals with their behavior as role models for students, habits and rewards stimulate students to behave and behave in a way character.

4. The teacher creates interesting and fun learning through Student Active Learning 
and Collaborative Learning methods. The majority of Pancasila and Citizenship Education Learning is carried out during the day, causing the concentration of students to decrease, so that the Pancasila and Citizenship Education teachers provide humor in the middle of learning that is being given so that students will enjoy learning activities without any pressure. According to the opinion of Indra Djati Sidi (2005), it is emphasized that arranging an attractive classroom learning environment and supporting students in learning is closely related to the physical environment of the class, room arrangement, student management and utilization of learning resources, class displays, and so on. According to Muhammad Saroni (2006), the point is that the physical environment is an environment that provides opportunities for movement and all aspects related to efforts to refresh the mind for students after following a very tedious learning process. The physical environment can function as a source or place for learning that is planned or utilized, which includes the physical environment, including classes that need to be optimized for management so that teaching and learning interactions are more effective and efficient.
Inhibiting Factors in the Development of Character Education through Learning of Holistic-Based Pancasila and Citizenship Education in Sungguminasa 1 State Junior High School, Gowa Regency.

Learning Pancasila and Citizenship Education is carried out at the second hour but is paused because of the student's break time so that the previous learning of Pancasila and Citizenship was not optimal which resulted in a decrease in student enthusiasm for learning and the appearance of drowsiness after resting. Therefore, teachers and staff must reconcile the student learning roster in order to optimize class hours with student breaks. Based on observations in class VIII.B, the printed books that should be the source of student learning are insufficient so that one printed book is divided into two or that it is divided into three. because that is one of the triggers of a lack of interest in reading in students due to the lack of printed books and this also has an impact on students when examining. According to Chambliss and Calfee's theory, as quoted by Muslich (2010) that textbooks are a tool for students to understand and learn from the things they read and to understand the world (outside themselves), textbooks have tremendous power against changes in the brain of learners. Textbooks can influence a child's knowledge and certain values. According to the experts above, the writer can conclude that the reference book is mandatory for use in schools which contains learning material in 
order to increase the ability to master science which is prepared based on national education standards.

\section{CONCLUSION}

Based on the results of research on the Implementation of Character Education through Learning Pancasila and Citizenship Education in Sungguminasa State Junior High School 1, Gowa Regency, the researchers concluded that the learning process of Pancasila and Citizenship Education class VIII.B Sungguminasa State Junior High School 1, Gowa Regency has been implemented by teachers through planning. In learning planning, there is a character value contained in self-development activities including routine, spontaneous and exemplary activities, while learning activities in the Learning Implementation Plan are in Core Competencies and Basic Competencies (KD). There are several supporting and inhibiting factors in the implementation of character education through learning Pancasila and Citizenship Education at SMP Negeri 1 Sungguminasa for VIII.B students, namely the supporting factors (1) The teacher invites students to create comfortable and conducive classes. (2) The teacher provides motivation and understanding of the importance of character values. (3) Teachers provide role models, advice, rewards and punishments, and accustom students to behave and behave with character, (4) Teachers create interesting and fun learning through Student Active Learning and Collaborative Learning methods. While the inhibiting factor is the non-conducive learning of Pancasila and Citizenship Education with student rest time which makes learning Pancasila and Citizenship hampered and students' enthusiasm for learning decreases and inadequate printed books for students which triggers a lack of reading interest in students due to the lack of printed books and this also has an impact in students when tests.

\section{REFERENCES}

[1] Abdullah Munir. (2010). Pendidikan Karakter. Yogyakarta: Pedagogia. Bandung: Bumi Aksara.

[2] Agustang, A., \& Sahabuddin, J. (2020, October). MODEL KOLABORASI SOSIAL PENDIDIKAN KARAKTER DI SEKOLAH SWASTA KECAMATAN BISSAPPU KABUPATEN BANTAENG. In PROSIDING SEMINAR DAN DISKUSI PENDIDIKAN DASAR.

[3] Budimansyah, Dasim \& Suryadi, Karim(2008). PKN dan Masyarakat Multikultural. Bandung: Prodi PKn SPsUPI

[4] Dinas P \& K. (2003). Kamus Besar Bahasa Indonesia. Jakarta: Bola Pustaka. Dharma Kesuma, dkk. 2011. Pendidikan Karakter: Kajian Teori dan Praktik di

[5] Doni Koesoema A. (2010). Pendidikan Karakter di Zaman Keblinger. Jakarta: Grasindo.

[6] Hellriegel \& Slocum. (1979). Organizational Behaviour (online pada 14 Juni 2014) Zubaedi. (2012). Desain Pendidikan Karakter. Jakarta: Kencana Prenada Media Group.

[7] Hasnah, K. (2020). PENGUATAN PENDIDIKAN KARAKTER: BERBASIS INTEGRATIF MORAL DI PERGURUAN 


\section{TINGGI (Vol. 1). CV. AA. RIZKY.}

[8] Hasnah, K., Amin, B., Syakur, A., \& Suardi, S. (2018). Peningkatan Hasilbelajar Bahasa Indonesia Melalui Model Pembelajaran Kooperatif Tipe Numbered Heads Together. JRPD (Jurnal Riset Pendidikan Dasar), 1(1), 25-33.

[9] Kebijakan Nasional, (2010). Pembangunan Karakter bangsa tahun 2010 - 2025

[10] Kementerian Pendidikan Nasional. Direktorat Jenderal Manajemen Pendidikan Dasar dan Menengah. Direktorat Pembinaan Sekolah Menengah Pertama. (2013). Pembinaan Pendidikan Karakter di Sekolah Menengah Pertama. Jakarta.

[11] Kohlberg, L. (1985). Stages Of Moral Development As a Basis Of Moral Education. Dalam C. Asri Budiningsih. 2004. Pembelajaran Moral Berpijak Pada Karakteristik Siswa dan Budayanya. Jakarta: PT. Rineka Cipta.

[12] Kanji, H., Nursalam, N., Nawir, M., \& Suardi, S. (2019). Evaluasi Integrasi Pendidikan Karakter dalam Pembelajaran Ilmu Pengetahuan Sosial di Sekolah Dasar. JED (Journal of Etika Demokrasi), 4(2).

[13] Kanji, H., Nursalam, N., Nawir, M., \& Suardi, S. (2020). INTEGRATION OF SOCIAL CARE CHARACTERS AND MORAL INTEGRATIF ON SOCIAL SCIENCE LESSONS IN ELEMENTARY SCHOOL. AL-ISHLAH: Jurnal Pendidikan, 12(2), 413-427.

[14] Kanji, H., Nursalam, N., Nawir, M., \& Suardi, S. (2019). MODEL INTEGRASI PENDIDIKAN KARAKTER DALAM PEMBELAJARAN ILMU PENGETAHUAN SOSIAL DI SEKOLAH DASAR. JURNAL PENDIDIKAN DASAR PERKHASA: Jurnal Penelitian Pendidikan Dasar, 5(2), 104-115.

[15] Kanji, H., Nursalam, N., Nawir, M., \& Suardi, S. (2020). Supporting and Inhibiting Factors of Character Education in Learning Social Studies at Primary Schools. JED (Journal of Etika Demokrasi), 5(1), 1-14.
[16] Masnur Muslich, (2010).Pendidikan Karakter Menjawab Tantangan Krisis Multidimesional. Jakarta: Bumi Aksara.

[17] Megawangi Ratna, (2015). Pendidikan yang Patut dan Menyanangkan. Jakarta: PT Global Aksara Pratama.

[18] Mei Kusumawardani. (2013) Implementasi Pendidikan Karakter Di Sekolah Menengah Kejuruan (SMK) Negeri 4 Yogyakarta”, Skripsi. Yogyakarta: Fakultas Teknik Universitas Negeri Yogyakarta,hal. 23-24.

[19] Muchlas Samani dan Hariyanto. (2011). Konsep dan Model Pendidikan Karakter.

[20] Mulyasa. (2004). Manajemen Berbasis Sekolah, Konsep, Strategi dan Implementasi. Bandung: PT Remaja Rosdakarya.

[21] Nursalam, Nawir, M., Suardi, \& Kanji, H. (2020). MODEL PENDIDIKAN KARAKTER PADA MATA PELAJARAN ILMU PENGETAHUAN SOSIAL DI SEKOLAH DASAR (Vol. 1). CV. AA. RIZKY. https://books.google.co.id/books?hl=id \&lr=\& $\mathrm{id}=8 \mathrm{tUKEAAAQBAJ} \& o \mathrm{i}=\mathrm{fnd} \& \mathrm{pg}=\mathrm{PA} 63 \& \mathrm{~d}$ $\mathrm{q}=$ buku+suardi+nursalam+pendidikan+karakt er\&ots=1A-g2fQs4\&sig=zVhj4kYePdGJVf09G419nxFsH4\&redir_esc $=y \# v=$ onepage \&q=buku suardi nursalam pendidikan karakter $\& \mathrm{f}=$ false

[22] Omar Hamalik. (2002). Perencanaan Pengajaran Berdasarkan Pendekatan Sistem.

[23] Rumiati, (2007). Pengembangan Pendidikan Kewarganegaraan. Jakarta: Dikti.

[24] Sagala, Syaiful. (2016). Konsep dan Makna Pembelajaran. Bandung: Alfabeta Sjarkawi. 2008. Pembentukan Kepribadian Anak Peran Moral, Intelektual, Sekolah. Bandung: PT Remaja Rosdakarya.

[25] Sudirman N. (2000). Ilmu Pendidikan. Bandung: Remaja Rosdakarya.

[26] Sugiyono. (2012). Metode Penelitian Kuantitatif Kualitatif dan R\&D. Bandung: Alfabeta. 
[27] Suyoto. (2011). Pendidikan Kewarganegaraan untuk Perguruan Tinggi, Yogyakarta: Graha Ilmu.

[28] Suardi, S. (2017). Peningkatan Hasil Belajar Sosiologi Pokok Bahasan Interaksi Sosial Melalui Metode Diskusi pada Siswa Kelas X MA. Muhammadiyah Panaikang Kacamatan Bissappu Kabupten Bantaeng. JED (Journal of Etika Demokrasi), 2(1).

[29] Suardi, \& Nursalam. (2020). Penerapan Model Pembelajaran Saintifik Approach Berbasis Media Classroom | Indonesian Journal of Sociology, Education, and Development. Indonesian Journal of Sociology, Education, and Devolopment, 2(2), 88-97. http://ijsed.ap3si.org/index.php/journal/article /view/vol2iss2_2020_2suardi

[30] Suardi, S., Herdiansyah, H., Ramlan, H., \& Mutiara, I. A. (2019). Implementasi Pendidikan Karakter Melalui Mata Pelajaran Pendidikan Kewarganegaraan di SMA Jaya Negara Makassar. JED (Journal of Etika Demokrasi), 4(1).

[31] Suardi, S., \& Kanji, H. (2018). Lecture Model of Student Transfer Discussion Method to Increase Student's Activeness and Learning Outcomes. Journal of Educational Science and Technology (EST), 4(1), 48-54.

[32] Suardi, S., Megawati, M., \& Kanji, H. (2018). Pendidikan Karakter di Sekolah (Studi Penyimpangan Siswa di Mts Muhammadiyah Tallo). JED (Journal of Etika Demokrasi), 3(1).

[33] Suardi, S. (2018). Penerapan Model Pembelajaran Saintifik Approacd Berbasis Media Pembelajaran Kearifan Lokal pada Mata Kuliah Dasar-Dasar Sosiologi dalam Membangun Karakter dan Meningkatkan Hasil Belajar Mahasiswa Pendidikan Sosiologi Universitas Muhammadiyah Makassar. JED (Journal of Etika Demokrasi), 3(2).

[34] Ulber Silalahi. (2010) . Metode Penelitian Sosial. Bandung: Refika Aditama.

[35] Undang-undang Sistem Pendidikan Nasional. 2009. Yogyakarta: Pustaka Belajar. Zuhdi, Darmiyati, dkk. 2014. Model Pendidikan Karakter. Yogyakarta: MP 